Atmawati, F., \& Permadi, A. (2019). Studi Kualitatif Fenomenologis: Motivasi Memakai Hijab Modis pada Mahasiswa. Indigenous: Jurnal Ilmiah Psikologi, 3(2). 70-78. doi: https://doi. org/10.23917/indigenous.v3i2.4973

\title{
Studi Kualitatif Fenomenologis: Motivasi Memakai Hijab Modis pada
}

\section{Mahasiswa}

\author{
Fitri Dwi Atmawati ${ }^{1}$, Aad Satria Permadi ${ }^{2}$ \\ Universitas Muhammadiyah Surakarta \\ atmawati@dw.comªad.satria@ums.ac.id²
}

\begin{abstract}
Hijab is a mandatory clothing for Muslim women. Along with its development, hijab is no longer considered a completely enclosed outfit depicting traditional, monotonous and ancient impression. Hijab comes with a variety of materials, colors and accessories so that the use of hijab not only limited to religious orders to cover aurat, but also as a symbol of Muslim women who follow the trend. Muhammadiyah University of Surakarta has regulations aimed at students to wear clothing that is in accordance with the norms of decency, decency, and religious teachings of Islam. However, many students are wearing tight clothing as well as overgrown to illustrate body shape. This study is qualitative research. The purpose of this study is to describe the motivation of students of Universitas Muhammadiyah Surakarta in wearing fashionable hijab. Informant of research as many as 6 people selected by purposive sampling that is student of Muhammadiyah University of Surakarta wearing fashionable hijab with age range 19 - 25 years. The results showed that motivation was influenced by intrinsic factors, namely lack of understanding on the rules of wearing hijab, unpreparedness of wearing syar'i clothes, and comfort, and extrinsic factors, namely conformity, freedom from parents, varied clothing models and reinforcement in the form of praise.
\end{abstract}

Keywords: Extrinsic Factor, Intrinsic Factor, Hijab Modis, Motivation.

Abstraksi. Hijab merupakan pakaian yang wajib dipakai oleh wanita muslimah. Seiring perkembangannya, hijab tidak lagi dipandang pakaian serba tertutup yang menggambarkan kesan tradisional, monoton dan kuno. Hijab hadir dengan bermacam-macam bahan, warna dan aksesoris sehingga penggunaan hijab tidak hanya sebatas perintah agama untuk menutup aurat, namun juga sebagai simbol wanita muslimah yang mengikuti trend. Universitas Muhammadiyah Surakarta memiliki peraturan yang ditujukan kepada mahasiswa untuk memakai pakaian yang sesuai dengan norma kesopanan, kesusilaan, dan ajaran agama Islam. Akan tetapi, banyak mahasiswa yang memakai pakaian yang ketat maupun terawang sehingga menggambarkan bentuk tubuh. Penelitian kualitatif ini mempunyai tujuan untuk mendeskripsikan motivasi yang dimiliki oleh mahasiswa Universitas Muhammadiyah Surakarta dalam memakai hijab Katakunci: Faktor ekstrinsik, Faktor Intrinsik, Hijab Modis, Motivasi. modis. Informan penelitian sebanyak 6 orang yang dipilih secara purposive sampling yaitu mahasiswa Universitas Muhammadiyah Surakarta yang memakai hijab modis dengan rentang usia 19 - 25 tahun. Teknik analisis data terdapat beberapa tahap yaitu: a) pengumpulan data, b) tahap reduksi data, c) tahap display data, d) tahap penarikan kesimpulan. Hasil penelitian menunjukan bahwa motivasi dipengaruhi oleh faktor intrinsik yaitu kurangnya pemahaman terhadap aturan memakai hijab, ketidaksiapan memakai pakaian syar'i, dan rasa nyaman, serta faktor ekstrinsik yaitu konformitas, kebebasan dari orang tua, model pakaian yang bervariasi dan reinforcement berupa pujian.

Kata kunci: Motivasi Ekstrinsik, Motivasi Intrinsik, Hijab Modis.

70 | Studi Kualitatif Fenomenologis... 


\section{PENDAHULUAN}

Agama Islam telah mengatur pakaianpakaian yang seharusnya digunakan oleh kaumnya, tujuan peraturan berpakaian dalam agama Islam adalah untuk menutup aurat. Imam Raghib (dalam Bahtiar, 2009) mengartikan hijab sebagai pakaian longgar yang terdiri atas baju panjang dan kerudung yang menutup badan kecuali wajah dan telapak tangan. Hijab pertama kali muncul di Arab lalu menyebar ke negara-negara Timur Tengah karena adanya perintah agama untuk berhijab bagi perempuan muslimah.

Pada abad 19 wanita muslimah di Indonesia menggunakan hijab dengan cara di-selampir-kan, di abad 20 hijab di Indonesia mulai bervariasi modelnya (Rakhmawati \& Handoyo, 2014). Hijab tidak lagi dipandang pakaian serba tertutup yang menggambarkan kesan tradisional, monoton dan kuno. Seiring perkembangannya, hijab hadir dengan bermacam-macam bahan, warna maupun aksesoris. Perkembangan tersebut didukung oleh tutorial-tutorial hijab di acara televisi, di majalah, hingga media sosial yang merebak di kalangan masyarakat. Penggunaan hijab tidak lagi hanya sebatas perintah agama untuk menutup aurat, namun sebagai simbol wanita muslimah yang mengikuti trend sehingga wanita muslimah lebih percaya diri.

Di Universitas Muhammadiyah Surakarta terdapat peraturan yang ditujukan kepada mahasiswa untuk berpakaian sopan sesuai dengan Surat Keputusan (SK) Rektor Universitas Muhammadiyah Surakarta Nomor: 076/I/2005 mengenai penyempurnaan tata tertib mahasiswa Universitas Muhammadiyah Surakarta pada Bab V Pasal 8 (10) yang menyatakan bahwa mahasiswa diharuskan berpakaian yang tidak melanggar norma-norma kesopanan, kesusilaan, dan ajaran agama Islam. Akan tetapi, banyak mahasiswa yang memakai pakaian yang ketat maupun terawang sehingga memperlihatkan bentuk tubuh

Bagi muslimah hijab merupakan identitas agama, kehormatan, pakaian taqwa, serta lambang rasa malu. Allah SWT memerintahkan wanita muslimah untuk menggunakan hijab yang tertulis dalam Firman-Nya, yakni:

Wahai nabi, katakanlah kepada istriistrimu, anak-anak perempuanmu dan istriistri orang mukmin, "Hendaklah mereka menutupkan jilbabnya keseluruh tubuh mereka". Yang demikian itu agar mereka lebih mudah untuk dikenali, sehingga mereka tidak diganggu. Dan Allah Maha Pengampun lagi Maha Penyayang (QS. Al Ahzab: 59).

Adapun syarat-syarat hijab menurut Albani (2002) yaitu: menutup tubuh selain yang dikecualikan, tidak untuk berhias, kain pakaian tebal/tidak tipis, longgar atau tidak ketat, tidak diberi wewangian atau parfum, tidak menyerupai pakaian laki-laki, tidak menyerupai pakaian orang kafir, tidak untuk mencari popularitas. Wanita muslimah yang berhijab tidak akan mendapatkan hal-hal yang menyakitkan serta pandangan-pandangan liar dan pelecehan seksual. Hijab menjadi benteng yang kokoh bagi wanita muslimah yang dapat melindungi dari laki-laki yang kurang baik. Pada saat wanita muslimah memakai hijab, pesona fisik dan daya tarik kewanitaannya tersembunyi. Orang-orang yang kurang baik mengetahui bahwa ada wanita muslimah yang menjaga kehormatannya, sehingga orang tersebut tidak mau mengganggunya.

Branca (dalam Walgito, 2010) menyatakan bahwa motif berasal dari bahasa Latin movere yang berarti bergerak atau to move. Manusia dalam bertindak, selain terikat oleh faktorfaktor yang datang dari luar, ditentukan pula oleh faktor-faktor yang terdapat dalam diri yaitu kekuatan yang berasal dari individu bersangkutan yang menjadi pendorong dalam tindakannya. Sehingga motif sebagai kekuatan yang terdapat dalam diri individu yang mendorong untuk berbuat atau merupakan driving force. King (2010) menyatakan bahwa faktor - faktor motivasi antara lain adalah motivasi intrinsik (intrinsic motivation), motivasi intrinsik didasarkan pada faktorfaktor internal, seperti kebutuhan organismik 
(otonomi, kompetensi, dan keterhubungan), aktualisasi diri, dan sebagainya.

Berdasarkan permasalahan tersebut, peneliti bertujuan untuk mengungkapkan faktor apa saja yang mempengaruhi motivasi mahasiswa Universitas Muhammadiyah Surakarta dalam memakai hijab modis dan Bagaimanakah dinamika motivasi mahasiswa Universitas Muhammadiyah Surakarta dalam memakai hijab modis.

\section{METODE PENELITIAN}

Penelitian ini adalah penelitian dengan metode kualitatif fenomenologis. Informan dalam penelitian ini sebanyak enam orang mahasiswa yang ditentukan dengan teknik purposive sampling. Informan dalam penelitian ini adalah enam orang mahasiswa Universitas Muhammadiyah Surakarta yang memakai hijab modis dengan rentang usia 19-25 tahun. Masing-masing berisial AS, NP, PN, AO, DA, dan DP.

Metode pengumpulan data dilakukan dengan cara wawancara terstruktur dan observasi tersamar. Strategi validasi dalam penelitian ini menggunakan membercheck. Data yang diperoleh lalu dianalisis dengan beberapa tahap yaitu: pengumpulan data, tahap reduksi data, tahap display data, tahap penarikan kesimpulan.

\section{HASIL DAN PEMBAHASAN}

Faktor-faktor intrinsik (King, 2010) merupakan faktor yang berasal dari dalam individu, yaitu kurangnya pemahaman terhadap aturan memakai hijab, ketidaksiapan memakai pakaian syar'i dan adanya rasa nyaman.

1. Kurangnya pemahaman terhadap aturan memakai hijab.

Informan AS, NP, dan PN, pertama kali memakai hijab ketika mulai awal memasuki universitas karena adanya peraturan dari pihak universitas yang mewajibkan seluruh mahasiswa muslim untuk memakai pakaian hijab ketika melakukan kegiatan di kampus.
Informan AO, DA, dan DP memakai pakaian hijab ketika SMA. Informan DP memakai pakaian hijab karena permintaan dari ibu, sedangkan informan $\mathrm{AO}$ dan DA memakai hijab untuk mematuhi peraturan yang dibuat oleh pihak guru. Berdasarkan pemaparan keenam informan, keinginan untuk memakai hijab tidak berasal dari dalam diri informan secara pribadi namun niat awal memakai hijab dipengaruhi oleh peraturan dari pihak guru SMA maupun universitas. Keenam informan menyatakan bahwa memakai hijab modis bukan hanya untuk mematuhi aturan atau norma sosial, namun juga sebagai bentuk mematuhi aturan agama secara perlahan yaitu menutup bagian-bagian tubuh dengan pakaian hijab modis. Keenam informan beranggapan bahwa pakaian hijab modis yang dikenakan tersebut telah sesuai dengan aturan dari sekolah/ universitas, maupun norma agama.

Norma sosial merupakan aturan-aturan yang seharusnya dilakukan seperti yang telah disepakati sebelumnya antara dua pihak atau lebih (Sarwono \& Meinarno, 2014). Adanya kesepakan tersebut, mendorong individu untuk mematuhi aturan-aturan dalam kehidupannya. Pihak universitas telah menentukan peraturan yang disepakati dengan calon mahasiswa sebelum memasuki universitas, sehingga calon mahasiswa yang telah diterima wajib memenuhi peraturan yang telah disepakati tersebut, termasuk aturan berpakaian yang sesuai dengan norma kesopanan, kesusilaan dan agama. Individu mengikuti norma sosial tidak terlepas dari adanya tekanan-tekanan untuk berperilaku dengan cara-cara yang sesuai dengan peraturan dalam suatu lingkungan. Adanya tekanantekanan tersebut memiliki pengaruh besar yang mendorong individu untuk berperilaku dengan cara-cara yang dipandang wajar atau dapat diterima oleh lingkungan.

Mahasiswa perempuan wajib memakai pakaian hijab ketika beraktivitas di kampus, ketika pada saat mahasiswa tidak mematuhi peraturan tersebut maka timbul tekanantekanan dari lingkungan misalnya diberi sanksi oleh dosen, atau mendapat tatapan tajam dari 
mahasiswalain sehingga merasa kurang diterima dalam lingkungan. Tekanan-tekanan tersebut mendorong informan untuk menghindari situasi tidak menyenangkan tersebut, sehingga informan mematuhi peraturan untuk memakai pakaian hijab ketika di lingkungan kampus agar dapat diterima secara wajar. Menurut informan, perempuan muslim wajib untuk mematuhi norma agama dengan cara menutup aurat. Norma agama adalah aturan yang berisi perintah, larangan serta anjuran yang berasal dari Tuhan dalam suatu ajaran agama. Norma agama mengharuskan penganut suatu agama untuk mematuhi segala perintah dan menghindari segala larangan Tuhan, serta tidak dapat diubah-ubah. Melanggar norma agama akan mendapatkan sanksi berupa dosa yang akan dimintai pertanggungjawaban saat di akhirat nanti. Informan memakai pakaian hijab modis sebagai proses untuk menaati aturan agama yaitu menutup aurat.

Aturan agama maupun aturan pihak universitas mewajibkan mahasiswa untuk berpakaian yang sesuai dengan syariat berpakaian, diantaranya menutup seluruh tubuh, tidak terawang serta tidak menampakkan bentuk lekuk tubuh. Informan beranggapan bahwa hijab modis telah menutup bagian-bagian tubuh dan lebih sopan dibandingkan pakaian non-hijab, sehingga telah sesuai dengan norma agama maupun peraturan dari universitas. Adanya ketidakselarasan antara aturan memakai pakaian hijab dengan pemahaman informan, menunjukkan bahwa informan kurang memahami hakikat memakai pakaian hijab seperti yang telah di-syari'at-kan

Berdasarkan pemaparan keenam informan tersebut, terdapat kurangnya pemahaman terhadap peraturan memakai pakaian hijab yang sesuai dengan norma agama maupun aturan dari Universitas sehingga informan tidak mengubah gaya berpakaian tersebut.

\section{Ketidaksiapan memakai pakaian syar'i}

Keenam informan merasa tidak siap ketika diminta memakai pakaian yang lebih longgar dan syar'i. Informan AO mengaku bahwa kurang menyukai model pakaian syar'i yang rata-rata berupa gamis/rok sehingga membatasi ruang gerak ketika beraktifitas. Informan $\mathrm{AO}$ masih tertarik untuk memakai dress yang menjadi trend sehingga memutuskan memakai hijab modis. Informan AS menganggap bahwa ketika memakai pakaian yang lebih syar'i maka akan terlihat lebih pendek tinggi badannya sehingga kurang proporsional dan tidak percaya diri.

Informan DA berpendapat bahwa pakaian syar'i hanya pantas dipakai oleh orang yang memahami ilmu agama, sedangkan informan DA merasa bahwa ilmu agama yang dipahami cenderung kurang sehingga merasa tidak pantas untuk memakai pakaian syar'i. Informan DP merasa bahwa perilakunya masih kurang baik sehingga khawatir apabila melakukan hal tersebut ketika memakai pakaian syar'i. Sedangkan informan PN merasa khawatir apabila tidak dapat secara konsisten memakai pakaian syar'i sehingga memutuskan memakai hijab modis. Ketidaksiapan informan tersebut dilakukan, maka akan timbul suatu kecemasan dalam diri informan. Freud (dalam Feist \& Feist, 2010) memaparkan bahwa kecemasan merupakan situasi afektif yang dirasa tidak menyenangkan yang diikuti oleh sensasi fisik yang memperingatkan seseorang akan bahaya yang mengancam. Nevid, Rathus, dan Beverly (2005) menyatakan bahwa ciri-ciri behavioral dari kecemasan antara lain, menghindar, melekat, terguncang. Berdasarkan hasil wawancara, timbul kecemasan ketika hendak memakai pakaian yang lebih syar'i sehingga respon dari kecemasan tersebut berupa perilaku menghindar yaitu menghindari memakai pakaian syar'i karena akan timbul suatu ketidaknyamanan sehingga informan memutuskan memakai hijab modis karena dianggap lebih nyaman.

\section{Rasa nyaman}

Informan $\mathrm{AO}$ merasa nyaman timbul ketika memakai hijab modis yang cenderung simpel sehingga lebih leluasa bergerak dalam beraktifitas. Informan $\mathrm{AO}$ tidak khawatir terhadap kerapian penampilan fisik ketika memakai hijab modis, sebab rambut dan sebagian wajah tertutup oleh kerudung sehingga timbul rasa percaya diri dalam diri informan. 
Informan AS merasa nyaman memakai hijab modis sebab telah terbiasa memakai pakaian tersebut sehingga tidak lagi merasa gerah. Informan AS menganggap bahwa hijab modis yang dikenakan tidak terlalu ketat dan matching sehingga tidak khawatir dengan tanggapan orang-orang disekitarnya. Informan DA dan DP berpendapat bahwa hijab modis yang dikenakan cukup sopan dan menutup tubuh sehingga merasa nyaman. Rasa nyaman tersebut menimbulkan rasa percaya diri dalam diri informan DA sehingga tidak merasa khawatir apabila dilihat maupun dikomentari oleh orang lain.

Pendapat yang sama juga dikatakan oleh informan DA, informan DP merasa percaya diri ketika pakaian hijab matching sehingga pantas dilihat oleh diri sendiri dan orang lain. Informan NP memaparkan bahwa merasa nyaman memakai hijab modis karena tidak membuat gerah. Sedangkan informan PN merasa nyaman ketika memakai pakaian yang tidak membuat gerah dan menutup tubuh. Perasaan nyaman mendorong untuk berperilaku memakai hijab modis, hal tersebut sesuai dengan pemaparan Theodore (dalam Santoso, 2010) bahwa faktor affect/perasaan berpengaruh pada pemberian motivasi ditinjau dari penerima motivasi, yaitu perasaan tidak mewakili bagian terpisah dari tingkah laku tetapi satu asumsi dimana perbuatan, persepsi dan pemikiran berlangsung.

Kenyamanan merupakan suatu kondisi dimana perasaan yang merasa nyaman berdasarkan persepsi masing-masing individu terhadap sesuatu hal. Theodore (dalam Santoso, 2010) menjelaskan bahwa faktor affect/perasaan berpengaruh pada pemberian motivasi ditinjau dari penerima motivasi; yaitu perasaan tidak mewakili bagian terpisah dari tingkah laku tetapi satu asumsi dimana perbuatan, persepsi dan pemikiran berlangsung. Ketika informan memakai hijab modis, rangsangan berasal dari indera peraba melalui nyaraf yang mempersepsi bahwa pakaian tersebut tidak panas, cukup menutup tubuh, serta memudahkan dalam bergerak, sehingga timbul kenyaman dalam diri informan. Ketika informan merasa nyaman memakai pakaian hijab modis timbul rasa percaya diri dalam diri informan. Informan merasa bahwa dengan memakai pakaian tersebut maka dapat diterima secara wajar dalam masyarakat, informan bebas memakai pakaian yang menjadi keinginannya karena cemas dan khawatir akan komentar orang lain sehingga hal tersebut mendorong informan untuk memakai pakaian hijab modis.

Pemakaian dan pemilihan hijab pada mahasiswa di penelitian ini, dipengaruhi oleh faktor ekstrinsik. Faktor-faktor ekstrinsik merupakan faktor yang berasal selain dari dalam individu atau segala sesuatu yang berasal dari luar individu yaitu konformitas, kebebasan dari orang tua, reinforcement berupa pujian dan banyaknya model pakaian yang bervariasi. 1. Konformitas

Pakaian hijab yang menjadi trend cenderung menampilkan model-model terbaru dan menarik sehingga membuat informan tertarik untuk membeli dan memakainya. Mengikuti trend merupakan bentuk dari konformitas, Baron, Branscomber dan Byrne (dalam Sarwono \& Meinarno, 2014) memaparkan bahwa konformitas adalah suatu bentuk pengaruh sosial dimana individu mengubah sikap dan tingkah lakunya agar sesuai dengan norma sosial. Mengikuti trend pakaian agar terlihat tidak ketinggalan jaman merupakan bentuk dari norma sosial yang bersifat descriptive norms yang biasanya bersifat implisit, tidak dinyatakan secara tegas atau tertulis (Sarwono \& Meinarno, 2014).

Berdasarkan hasil wawancara, saran dari teman memiliki pengaruh terhadap gaya berpakaian informan. Informan cenderung menerima saran dari teman-teman saat memilih pakaian karena minat terhadap gaya pakaian yang cenderung sama. Informan menganggap bahwa saran dari teman-teman yang diterima mengenai dirinya adalah sesuatu yang positif sehingga informan berusaha memenuhi saran tersebut. Penelitian Sherif (dalam Sarwono \& Meinarno, 2014) menjelaskan bahwa norma sosial berkembang dalam situasi ambigu. Ketika situasi ambigu, situasi menjadi tidak jelas atas apa yang harusnya dilakukan, 
maka individu cenderung mencari kejelasan lewat kelompok dengan mengikuti apa yang diharapkan oleh kelompok. Kesimpulannya, informan melakukan konformitas terhadap norma kelompok. Ada kebutuhan kuat dalam diri manusia untuk bertindak benar atau tepat sehingga bisa diterima dan disukai oleh orang lain.

Selain mengikuti saran dari teman sebaya, informan mendapatkan inspirasi memakai hijab modis melalui internet. Seseorang dapat dengan mudah mendapatkan informasi secara mudah, banyak informasi yang dihadirkan oleh berbagai situs internet sehingga pengguna dapat mengkases dalam waktu yang relatif cepat. Trend pakaian hijab banyak ditampilkan dan diakses pada media sosial. Melalui media sosial informan mengakses foto maupun video tutorial pemakaian hijab yang diperagakan oleh selebgram yaitu sebagai model yang diamati, sehingga ide-ide muncul setelah informan mengamati foto atau video tersebut. Terdapat proses modelling ketika informan mengakses akun selebriti instagram. Modelling adalah proses belajar dengan mengobservasi tingkah laku dari model. Modelling bukan hanya sekedar perilaku meniru atau mengulang apa yang dilakukan oleh model (individu yang menunjukkan tingkah laku) tetapi dalam proses modelling melibatkan perubahan, atau pengurangan tingkah laku yang diamati, sekaligus juga melibatkan proses kognisi (Rahmi, 2015).

Informan melihat dan mengamati gambar atau video tutorial cara pemakaian hijab lalu mengingat dan memproduksi cara pemakaian hijab tersebut dalam kognisinya. Setelah mempelajari dan mengetahui cara pemakai hijab modis, informan memutuskan untuk meniru gaya pakaian tersebut dengan melakukan konformitas terhadap gaya pakaian selebgram (selebriti instagram) yaitu memakai pakaian dengan gaya hijab modis.

\section{Kebebasan dari orang tua}

Orangtuainforman cenderung memberikan kebebasan kepada informan dalam memilih gaya berpakaian. Orang tua hanya memberi nasehat dan saran, namun tidak memberikan sanksi khusus ketika informan memakai hijab modis maupun tidak memakai pakaian hijab pada saat keluar rumah. Hasil wawancara tersebut sesuai dengan pendapat Strickand (dalam Hanurawan, 2010) yang menyatakan bahwa komponenkomponen utama keluarga seperti ayah, ibu, dan saudara memiliki peran yang penting dalam perkembangan anak untuk mengenal nilai-nilai dan keyakinan-keyakinan sosial budaya yang dianut oleh sebuah keluarga.

\section{Model pakaian yang bervariasi}

Hijab modis hadir dalam berbagai warna dan model, berbagai bahan seperti sifon, katun, jeans dan lain-lain. Selain itu, pakaian hijab modis memiliki banyak model yang dapat dipadukan dengan berbagai model pakaian yang lain sehingga terlihat lebih menarik. Modelmodel pakaian tersebut antara lain pashmina yaitu kerudung panjang yang dapat dikreasikan dengan berbagai bentuk sesuai dengan minat, hijab instan yang dapat langsung dipakai tanpa harus disematkan jarus saat pemakaiannya sehingga lebih praktis, model tunic yaitu pakaian atasan dengan panjang hingga lutut sehingga menutupi badan bagian belakang. Hurlock (2003) yang menyatakan bahwa minat terhadap pakaian tidak menjadi berkurang dengan bertambahnya usia, bahkan perhatian ini bertambah apabila orang merasakan manfaat pakaian yang mahal atau menarik dalam pergaulan yang dianggap penting bagi seseorang, sehingga berbagai macam model yang bervariasi tersebut mendorong informan ingin memakai pakaian hijab modis karena dianggap lebih menarik.

\section{Reinforcement berupa pujian}

Menurut Santoso (2010) ganjaran berarti konsekuensi menyenangkan atau tidak menyenangkan bagi individu. Ganjaran yang menyenangkan (reward) dapat menciptakan kebiasaan, sedangkan ganjaran yang tidak menyenangkan (punishment) seperti hukuman cenderung menghapus tingkah laku. Reward berupa komentar atau pujian yang didapatkan oleh informan dapat membentuk kebiasaan dalam memakai hijab modis. Keenam informan 
mendapatkan komentar maupun pujian bahwa lebih cocok memakai pakaian hijab modis, sehingga informan merasa lebih disegani dan dihargai. Informan merasa dihormati ketika tidak lagi dipanggil dan disiuli pada saat melewati sekelompok laki-laki.

Hal yang tidak menyenangkan saat memakai hijab modis yaitu sikap orang lain yang memperhatikan penampilan informan secara terus menerus, serta mendapat teguran teman karena pakaian yang cenderung ketat sehingga informan berusaha mengganti pakaian. Feist dan Feist (2010) menambahkan bahwa hukuman biasanya diberikan untuk menahan seseorang bertindak dengan cara tertentu. Apa yang akan dilakukan seseorang tidak dapat diprediksikan secara akurat karena hukuman tidak memberitahu apa yang harus dilakukan, hukuman hanya akan menekankan kecenderungan untuk bertindak dalam suatu cara. Berdasarkan hasil penelitian, reward yang didapatkan oleh informan lebih banyak dibandingkan dengan punishment yang diterima informan sehingga timbul perilaku berpakaian dengan gaya hijab modis.

Adanya faktor-faktor yang telah dipaparkan, baik faktor intrinsik maupun ekstrinsik menimbulkan dorongan-dorongan motivasi dalam diri informan untuk memakai pakaian hijab modis. Maka timbul perilaku berpakaian hijab modis yang ditandai dengan memakai pakaian tidak sepenuhnya menutup tubuh, misalnya memakai pakaian dengan lengan sepanjang siku, tidak memakai kaos kaki serta memakai kerudung namun menampakkan sebagian rambut. Pakaian cenderung terawang dan ketat meskipun menutup sehingga masih menggambarkan bentuk tubuh misalnya kaos, kemeja, tunic, cardigan, dan sebagainya.Selain itu, informan memakai kerudung pashmina maupun segiempat yang dapat dikreasikan dalam berbagai bentuk dan model sehingga lebih menarik.

Adanya perilaku memakai pakaian hijab modis tersebut, mendatangkan berbagai tanggapan dari orang disekitar informan. Tanggapan tersebut merupakan bentuk dari reinforcement yang merupakan penguatan terhadap perilaku yang akan terjadi, yang berupa penguatan positif (reward) dan penguatan negatif (punishment). Skinner (dalam Faidy \& Arsana, 2014) berpendapat bahwa tingkah laku pada dasarnya merupakan fungsi dari konsekuensi tingkah laku itu sendiri, apabila munculnya tingkah laku diikuti dengan sesuatu yang menyenangkan (reward), maka tingkah laku tersebut cenderung untuk diulang. Sebaliknya, jika munculnya tingkah laku diikuti dengan sesuatu yang tidak menyenangkan (punishment), maka tingkah laku tersebut cenderung tidak akan diulang. Informan mendapatkan komentar positif berupa pujian bahwa lebih cocok dan cantik, tidak lagi digoda saat bertemu dengan sekelompok laki-laki ketika memakai hijab modis sehingga merasa senang, dihargai, dan merasa mendapatkan reward. Adapula tanggapan negatif yang diperoleh informan, antara lain merasa diperhatikan oleh orang lain serta mendapat teguran dari teman pada saat memakai pakaian yang cenderung ketat atau tidak matching, sehingga merasa mendapatkan punishment dan menghindari situasi tersebut dengan mengganti dengan pakaian lain.

Skinner (dalam Andriyani, 2015) menambahkan bahwa setiap tingkah laku yang spesifik yang telah direspon, perlu diberi hadiah (reward) agar tingkah laku itu terus menerus diulang, serta untuk memotivasi agar berlanjut kepada komponen tingkah laku selanjutnya sampai akhirnya pada pembentukan tingkah laku puncak yang diharapkan. Dalam penelitian ini, reward yang diterima informan lebih besar dibandingkan punishment yang diterima oleh informan, oleh sebab itu reward memberikan pengaruh secara langsung terhadap terbentuknya motivasi memakai hijab modis, sehingga kembali memunculkan perilaku memakai hijab modis hingga membentuk suatu kebiasaan. 


\section{SIMPULAN}

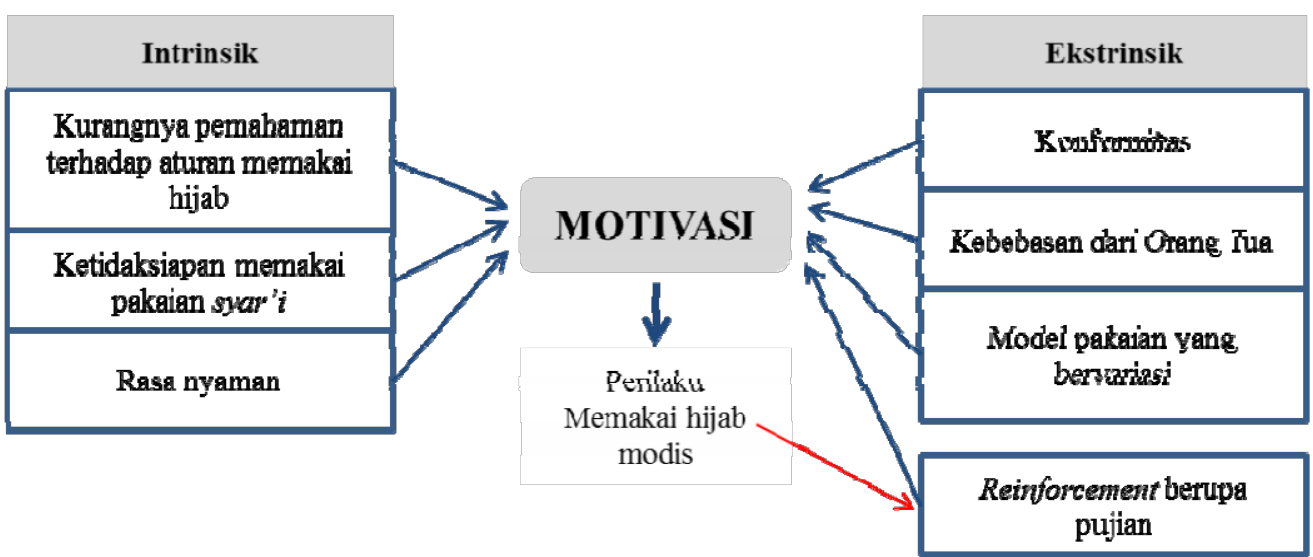

Gambar 1.Dinamika Motivasi Memakai Hijab Modis pada MahasiswaUniversitas Muhammadiyah Surakarta.

Motivasi mahasiswa memakai hijab modis adanya rasa nyaman, sedangkan faktor ekstrinsik pada Universitas Muhammadiyah Surakarta merupakan faktor yang berasal selain dari dipengaruhi oleh faktor ekstrinsik dan faktor dalam individu atau segala sesuatu yang berasal intrinsik. Faktor intrinsik merupakan faktor yang dari luar individu yaitu konformitas, kebebasan berasal dari dalam individu, yaitu kurangnya dari orangtua, reinforcement berupa pujian, dan pemahaman terhadap aturan memakai hijab, banyaknya model pakaian yang bervariasi. ketidaksiapan memakai pakaian syar'i, dan

\section{DAFTAR PUSTAKA}

Albani, M. N. (2002). Jilbab Wanita Muslimah. Solo: At Tibyan.

Andriyani, F. (2015). Teori Belajar Behavioristik dan Pandangan Islam tentang Behavioristik. Jurnal Pendidikan dan Pranata Islam, 10 (2), 165-180.

Bahtiar, D. S. (2009). Berjilbab dan Tren Buka Aurat.Yogyakarta: Mitra Pustaka.

Baron, R., \& Byrne, D. (2002). Psikologi Sosial. Jakarta: Erlangga.

Faidy, A. B., \& Arsana, I. M. (2014). Hubungan Pemberian Reward dan Punishment dengan Motivasi Belajar Pendidikan Kewarganegaraan SiswaKelas XI SMA Negeri 1 Ambunten Kabupaten Sumenep. Kajian Moral dan Kewarganegaraan, 2 (2), 454-458.

Feist, J., \& Feist, G. J. (2010). Teori Kepribadian: Theories of Personality. Jakarta: Salemba Humanika. Hanurawan, F. (2010). Psikologi Sosial. Bandung: Remaja Rosdakarya.

Hurlock, E.B. (2003). Psikologi Perkembangan: Suatu Pendekatan Sepanjang Rentang Kehidupan. Jakarta: Erlangga.

King, L. (2010). Psikologi Umum. Jakarta: Salemba Humanika.

Nevid, J. D., Rathus, S. A., \& Beverly, G.(2005). Psikologi Abnormal. Jakarta: Salemba Humanika.

Rahmi, S. (2015). Pengaruh Pendekatan Perilaku Kognitif terhadap Tingkat Penyesuaian Diri Siswa di Kelas VII Smp Negeri 29 Makassar. Jurnal Psikologi Pendidikan dan Konseling, 1 (1), 28-38.

Rakhmawati, H. N., \& Handoyo, P. (2014). Konstruksi Diri Komunitas "Hijabee" Surabaya terhadap Hijab. Paradigma. 2 (3), 1-8. 
Santoso, S. (2010).Teori - Teori Psikologi Sosial. Bandung: Refika Aditama.

Sarwono, S.W., \& Meinarno, E. (2014). Psikologi Sosial.Jakarta: Salemba Humanika.

Walgito, B. (2010). Pengantar Psikologi Umum. Yogyakarta: Andi. 